\title{
Computer Simulation Research for Infant Industry Theory based on Repast Simphony
}

\author{
http://dx.doi.org/10.3991/ijoe.v11i7.4760 \\ Y.F. Lin, Z.E. Nong \\ Guangxi University of Finance and Economics, Nanning, China
}

\begin{abstract}
Through analyzing logical defects of Friedrich List's infant industry theory, this paper obtains two hypothesis. One is that no industry is with single product portfolios, and so it is difficult for the developed countries defeating under-developed countries' infant industry completely according to the comparative advantage theory. This implies that under-developed country could obtain more survival opportunities if it leverages appropriate product diverse strategies. The other hypothesis is protecting infant industry by tariff barriers would increase the cost of whole society, which slows down the development of infant industry, and that damaging interests of both backward country and powerful country. We construct a computer simulation model on Repast Simphony platform to verify the above two hypothesizes, and our simulation results show that the above two hypotheses make sense. We also got an unexpected result that it will lead to significant decline of the yield of the infant industry if one country in the trade exerts tariff barriers, meanwhile, the yield of the other countries will also decline but the decreased amount of the infant industry of the under-developed country obviously exceed the developed country, which means the trade protection damages both side of trade and the underdeveloped country get more injury. That implies the assumption of the tariff barriers protecting and accelerating the development of infant industry does not make sense.
\end{abstract}

Index Terms-infant industry; tariff barriers; computer simulation; Repast Simphony

\section{INTRODUCTION}

For a long time, people consider that, for a huge country, the trade protection by tariff barriers or non-tariff barriers is beneficial to the development of infant industry in its early day. The typical example is Friedrich List who proposed trade protection theory. Protecting infant industry becomes popular practices by every country in the past 50 years; lots of people challenge this practice although a certain protection to infant industry doesn't violate related WTO rules. The core issue of this challenge is the selection of infant industries. There are selection criteria including so-called Mill's text( production cost is higher than international market price), Bastable's text (the discount value of future anticipated profit is higher than protect cost), Kemp's text(only when the protected pioneer corporations get achievements it could bring positive economic externalities to other domestic corporations in learning process, the protection to pioneer corporations is reasonable.), etc. All criteria couldn't answer the following questions. Firstly, why is government so confidant with the protection being able to promote the development of this industry. Namely, there are lots of industries that the production cost of corporation is higher than international market price, how government understands which industry has potential to grow up by leveraging appropriated protection? Secondly, how government knows which industries" "discount value of future anticipated profit is higher than protect cost"? Finally, how government knows "the achievement of the pioneer corporations' learning curve could bring positive economic externalities to other domestic corporations"? Is government a prophet in some sense? Because these challenges some papers switches to the research about optimum path of protection.

We agree above challenges, but it is noted that there are two queries that never been mentioned before. The first query is that: couldn't infant industry survive and develop without government's tariff barriers protection? The second query is that: could infant industry grow quickly with government's tariff barriers protection?

The aim of this paper is to review Friedrich List's trade protection theory, and verify two theoretical hypotheses about above two challenges.

The first theoretical hypothesis is: infant industry could survive and develop in free trade.

The second theoretical hypothesis is: the grow speed of infant industry protected by government's tariff barriers is lower than under the free trade.

We arrange the rest of this paper as follow: the second part of this paper is brief comments about the logic defects of Friedrich List's trade protection theory and the derivation of our theoretical hypotheses; the third part of this paper is the construction of a computer simulation model based on Repast Simphony platform and the description of "agent's" behavior criterion and constraints; the fourth part is the introduction of the basic architecture and main program of computer simulation program; and then is the description of the experimental results of the computer simulation result and the explanation of result; the last part is the conclusion of research.

II. THE LOGIC VULNERABILITY OF LIST'S TRADE PROTECTION THEORY ABOUT INFANT INDUSTRY AND THE DERIVATION OF THIS PAPER'S THEORETICAL HYPOTHESES

The main points of List's trade protection theory about infant industry is that infant industry has potential capability to develop but it would be defeated and killed by strong foreign competitors during infancy without government's protection. If government keeps strong foreign competitors out of country by tariff or non-tariff barriers, it would be beneficial to the development of infant industry and the development of country's 
economic if government open market after infant industry grows up.

Firstly, let's analyze the first theoretical hypothesis which is whether infant industry could survive without government's protection. It is a mistake that List though the product of an industry is homogeneous and not diverse. Infant industry couldn't survive logically if competitors have significant advantages in an industry with single product. However, this hypothesis doesn't make sense practically. No industries have only one kind of products, and every industry has at least two kinds of products in real world. For example, could readers image there are more than two kinds of products in water supply industry? Actually, the answer is yes. There is difference in service quality even the quality of water is same, so water supply industry has more than two kinds of products. The other example is soybean. The advantages of America soybean are low cost and high yield because much more cultivated land available. Therefore, we turn to planting green organic soybean. American soybean and Chinese soybean are two different kinds of products for different tastes. According to the relative comparative advantage theory of international economics, backward country will get "relative comparative advantage" on one kind of products and survive if there are two kinds of products available and both have certain market share. Actually, the so-called relative comparative advantage means although the under-developed country gets more advantage on product $\mathrm{A}$ and $\mathrm{B}$, but the profit of Product A is more than Product B, so, the developed countries would put all resources on the product $A$ instead of product $\mathrm{B}$ according to the basic assumption of economic man that a man naturally maximizing his own interests. In result, the under-developed country could produce product $\mathrm{B}$.

Certainly, the powerful country could manufacture both products when powerful country put all resources on product $\mathrm{A}$ and the gained profit rate of product $\mathrm{A}$ reduced because of competition-the decreasing degree depend on market demand. Therefore, the gained profit rate of product A could reduce to the same level of product $B$ theoretically, and so the developed country produces both products. The under-developed country completely fails if the powerful country has ability to fulfill the whole market demand. But most of industries have diverse products and market needs. And so, it is rare that the gained profit rate of all products is exactly equivalent.

In practice, the "relative comparative advantage theory" of international economics plays a role in most cases. Let's take grain as an example. Although the production efficiency of American grain is high and its cost is low, Chinese farmers could produce green food with farmyard manure to compete with American grain, and people would purchase Chinese grain even if cost, price are high, and less stock available. Chinese agriculture industry hasn't significantly diminished and falls into recession for the sake of tariff since China joined WTO.

In a word, the under-developed country has survival chance only if the powerful country couldn't cover the whole market demand, and also the under-developed country could survive only if the profit rates of all products don't completely equal (the probability to reach this specific case is low) even the developed country could satisfy the whole market demand.

The following analysis is whether it would be beneficial to the development of infant industry if country exerts trade barriers. People who support List's theory thought trade protection could bring more profits to protected infant industry, and so that this infant industry has more research fund for the further development, which would accelerate the development of this industry. We consider there are two logical defects on this viewpoint.

The first logical defect is whether tariff barriers protection could make more profits to the protected industry. From the perspective of logical deduction, if country keeps competitor's lower price products out of gate, the price of product would be higher but the profits is uncertain because profits equivalent to price subtracts cost. People who thought trade protection brings high profit consider trade protection wouldn't lead to higher cost. In fact, trade protection makes the cost of all customers in this industry increase, so that the cost of other products increase, and finally the cost of infant industry protected by trade protection increased.

The second logical defect is the protected industry may not have initiative to put profit on development and research even it gains high profit. Managers may put on enjoyment. That means we could reasonably assume those stakeholders of the protected industry have no initiative to do innovation. So the result is contrary to List's conjecture. The development speed of protected industry essentially becomes slow.

The following part is the confirmation about our judgment by means of computer simulation experiments.

\section{COMPUTER SIMULATION MODEL BASED ON REPAST SIMPHONY: BEHAVIOR RULE AND RESOURCE ENDOWMENT}

The simulation study is based on the complex adaptive system theory ${ }^{[2]}$, which is proposed by J. Holland of the Santa Fe Institute in 1994 and this theory has been widely applied in economics ${ }^{[3]}$, ecological ${ }^{[4]}$, computer network [5] and other research fields. At the time, typical simulation platform used to study complex adaptive system are Swarm, MASON, Netlogo, Repast Simphony and so on ${ }^{[6]}$. Our research takes Repast Simphony simulation platform developed by the Social Scientific Computing Research Center of as research tool, which is suitable for multi-agent modeling and is a formal simulation tool to study complex adaptive system. Repast Simphony offers a series of class libraries to generate, operate, and collect information, and it could run abstract model, observe evolution process, and observe explicitly result, which provides a convenient method to study. Right now, simulation research about trade protection is rare, only few papers mention this field. XueYan Shao studies trade policies of technical barriers by means of computer simulation approach after analysis of the setting motivation and mechanism of the technical barriers ${ }^{[7]}$. 
JianYe Jiang does research about technical barriers based on the measuring and calculating method of the technical barriers and computer simulation technologies ${ }^{[8]}$.

According to the situation of real international trade, we extract key elements of complex trade system to prepare the construction of simulation model. We assume there are three countries which are country A, country B, and country $\mathrm{C}$, and all these countries manufacture tools, fruits and gold coins. All countries produce fruits as indispensables for life and the excess part of fruits could be sold in domestic market or international market. Tools are used to improve productivity, except the essential tools to satisfy the production of fruits, the excess part of tools also could be sold in domestic market or international market. Meanwhile, gold coins could be gained from trade or the production of gold coins. The 'agent' in model has following specific behavior rules:

(i) Agent could choose. Every moment, agent makes decisions of whether to produce fruit, or whether to dig gold coin, or whether to produce tool, or whether to purchase them, or whether to select vendor. The selection rules are the same as reality, which are agents being able to choose the most favorable action plan for them. Namely, they would choose the plan with minimum cost, which might be from purchase or production. That means if the cost of production is lower than average price in market, they produce. Otherwise, they purchase items from market.

(ii) The rules of production. Agent must randomly move to seek productive point to produce--the cost of production depends on the distance of movement, and the distance would be converted to unit production costevery unit production cost consume one gold coin, and agent's strength come from fruitseach fruit generates $1 / 2$ unit strength, and agent couldn't manufacture products without strength. The approach of gaining fruit is to produce or purchase fruit. The approach of producing fruit is to pick fruit from fruit trees by moving and seeking the nearest fruit trees (picking consumes strength, and it couldn't pick fruit or dig gold coin or tool without strength). The approach of purchasing fruits is to move continuously to seek and trade with other agents nearby-trade by exchanging gold coin or tool. Agents gain gold coins through selling their products or digging gold coins from gold mine. The approach of digging gold coin is to move and seek near gold mine, and then excavate gold coins-excavating one gold coin consume one unit strength. The approach of producing tool is similar with the approaches of producing fruit and gold coins, namely, agents should move and seek tool through burial ground.

(iii) Selection of production mode: agents select products and which method to produce. There are two approaches producing fruits, one is to produce by hand, the other is produce by "tool", and the yield of production by tools in unit time is higher than by hands. How to get tools to improve the productivity depends on situation, namely, it is prior to use inventory tools to produce fruits, and agents could purchase or produce tools if there are no inventory tools. Comparing to the cost of purchasing and producing, agents select the low cost method to get tools. The tools couldn't be obtained if agents have no gold coins or strength to produce tools. Agents have to eat fruit to generate strength to produce tools, or gain gold coins by trade.

(iv) The rules of trade and selection. The average price of market is statistical variable, which is the average of real transaction price in a certain unit time. In this model, we assume every agent have full knowledge of the average market price in past anytime free of charge. The market in this model is not a perfectly free market, and the practical bargain price is not always the average market price. The practical transaction price comes from the following trade rules:

Agents move randomly to trade point where agents conduct international trade and domestic trade, and they bargain with each other if there are 'international man' and 'domestic man' selling fruits or tools. Vendors bid according to their cost of production and marketing (main cost is tariff), while vendee trades vendor who bids lowest price by comparing production cost with vendors' bidding, and vendee continues to seek the next vendor if all vendors' bidding are lower than production cost.

(v) Country and tax collector. There are three countries in our simulation model which are country A, country B and country C, all agents in these countries could only produce in their own countries, but they could buy and sell in other country. Every tax collector collects import tariff (from exporter) based on tariff rate of tax policies. Tax collector is another program instead of agent-program responds to count import tariff. The import tariff would be added into the cost of product.

(vi) Other rules and instructions

(a) Production needs sufficient strength;

(b) Only gold coins could be used to pay trade; gold coins couldn't be traded but purchase; 
(c) Tariff policy is the only concerned government influence factor.

(d) The calculation of GDP is counted by production method:

Total GDP= fruit GDP + tool GDP + gold coin GDP + service GDP

Fruit GDP $=$ yield of fruit $\times$ market price of fruit - usage of tool $\times$ market price of tool

Tool GDP $=$ yield of tool $\times$ market price of tool

Gold coin GDP= yield of gold coin $\times$ market price of gold coin

Service GDP= the amount of levied tariff

\section{DESIGN OF SIMULATION PROGRAM}

We divide simulation system into four parts that are gsblfzbuilder.java, Aren.java, Bren.java and Cren.java, and we compile program accordingly, which is our basic thinking of the design of simulation program. The initialization program is gsblfzuilder.java, and all necessary initial parameters, space and grid would be initialized in this program. It is necessary to set program's operation, so that we could change parameters to do different experiments under different scenarios. gsblfzbuilder.java is programming as follow:

public class gsblfzbuilder implements ContextBuilder $<$ Object $>\{$

public double ABgzgs,BAgzgs ,CAgzgs,......;//tariff

public Context build(Context $<$ Object $>$ context) \{

ContinuousSpaceFactory spaceFactory $=$

ContinuousSpaceFactoryFinder.createContinuousSpaceFactor

$\mathrm{y}($ null);

$$
\text { GridFactory gridFactory }
$$

GridFactoryFinder.createGridFactory(null);

int ArenCount $=($ Integer)params.getValue("Aren_count"); //get initial parameters

for (int $\mathrm{i}=0 ; \mathrm{i}<$ ArenCount; $\mathrm{i}++$ ) \{

//assign initial strength int energy $=$ RandomHelper.nextIntFromTo(40, 80);

context.add(new Aren(space, grid, energy)); \}

Aren.java, Bren.java, and Cren.java are the programs that create three different countries' agents. Take country A as example, the program shows as follow:

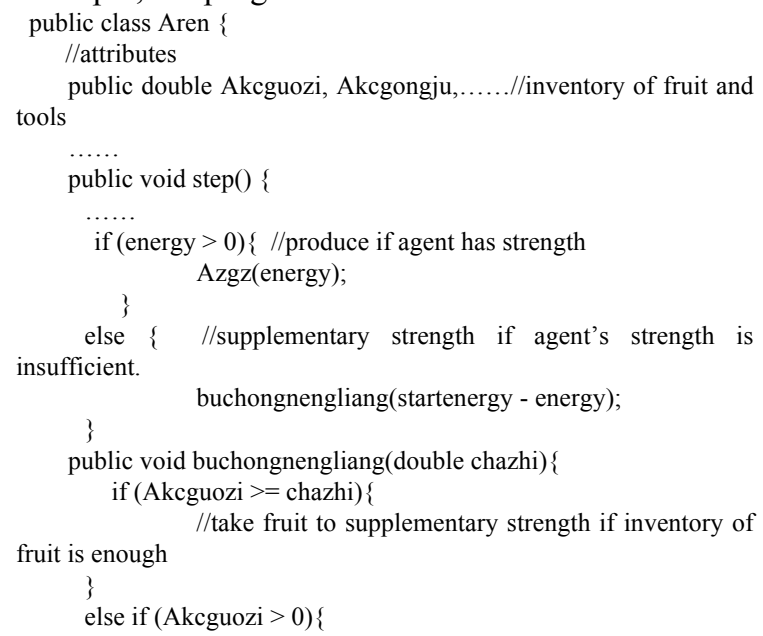

//inventory of fruit can only supplementary parts of strength and agent purchase fruit if there is no inventory of fruit ABmgz(chazhi); //purchase fruit

else $\{$ //inventory is empty if $($ Akcjinbi $>0)\{$ ABmgz(chazhi); //purchase fruit to

supplementary strength if agent has gold coin \} else \{

Azgz(chazhi); //produce by self<smiles>IC[I-]</smiles>

\}

The design of agent program is to simulate the basic activities of natural person in market dealing. Agent gets initial value from gsblfzbuilder.java, and may produce or purchase based on the situation of inventory, strength and market demand in program execution. Each agent could move and make market deals. Firstly, agent moves to a transaction point and do polling with native or foreign agent to ask whether to trade, and they would bargain with each other based on market price and make a deal with the lowest price if the deal is conducted, and if deal is closed, agent moves to next transaction point and repeat above transaction process. This process could happen in the trade between countries or domestic agents, which depends on market price. The process of simulation shows as figure 1 .

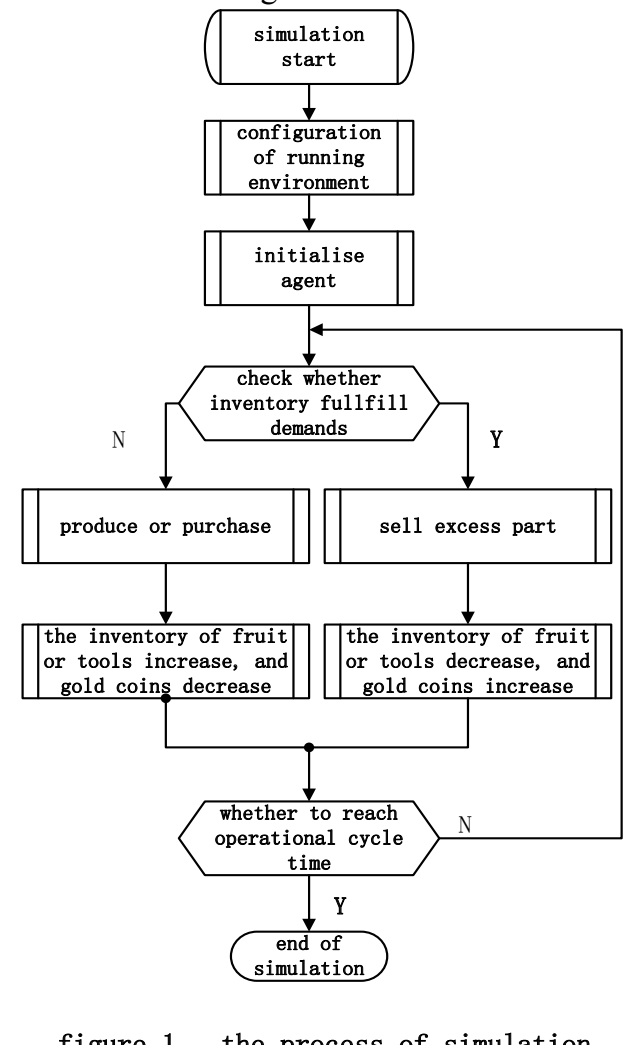

figure 1 the process of simulation

Input program to Repast Simphony simulation platform, and set initial condition, then we can start experiment. The running state shows as figure 2 and figure 3 . 
PAPER

COMPUTER SIMULATION RESEARCH FOR INFANT INDUSTRY THEORY BASED ON REPAST SIMPHONY

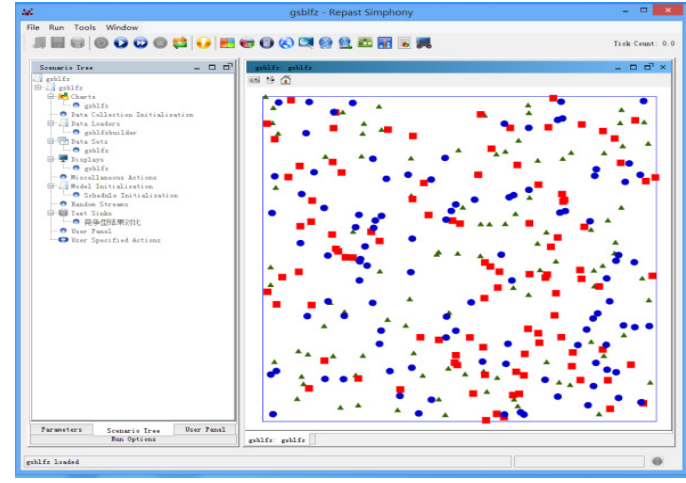

Figure 2. Running state of program

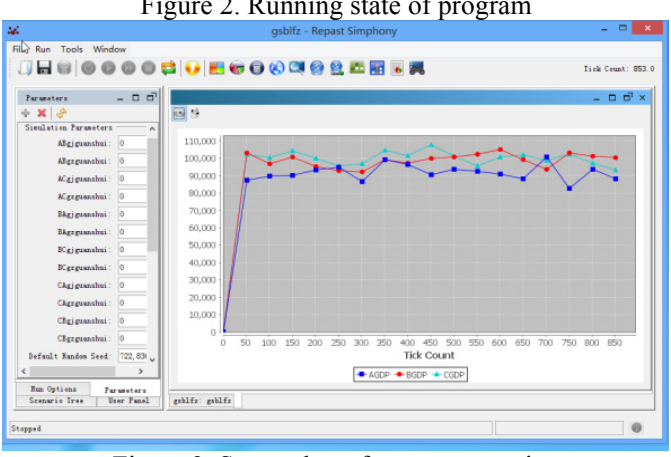

Figure 3. Screenshot of program running

\section{EXPERIMENT RESULT AND ANALYSIS}

We put experiment condition into coded simulation program, and do three different experiments that have different initial condition.

(1)the first experiment: initial condition and experiment result

The configuration of the first experiment's condition is showed as table I.

TABLE I.

CONDITON OF SIMULATION EXPERIMENT

\begin{tabular}{lccc}
\hline name & $\begin{array}{l}\text { amount(country } \\
\text { A) }\end{array}$ & $\begin{array}{l}\text { amount(country } \\
\text { B) }\end{array}$ & $\begin{array}{l}\text { amount(country } \\
\text { C) }\end{array}$ \\
\hline Agent & 100 & 100 & 100 \\
Fruit tree & 100 & 300 & 500 \\
tool & 200 & 400 & 600 \\
gold & 100 & 100 & 100 \\
mine & 850 & 850 & 850 \\
cycle & & & \\
time & & &
\end{tabular}

Agent is the number of people who participate in the production and trade, because the distribution density of fruit trees and tools of every country is different, the cost of production is different. When country A taxes on fruits from country B and country C, and country B and country $\mathrm{C}$ don't tax on fruits from their countries, the experiment result is showed in table II.

TABLE II.

TARIFFS OF COUNTRY A COLLECT FROM THE FRUIT OF

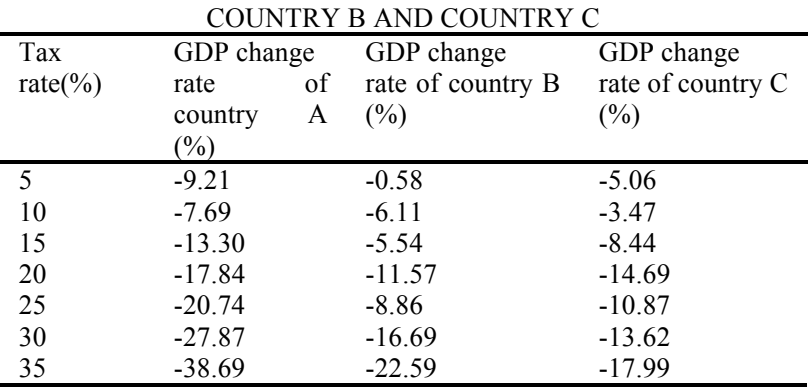

\begin{tabular}{llll}
\hline 40 & -42.48 & -31.91 & -13.46 \\
45 & -62.25 & -41.22 & -25.40 \\
50 & -75.72 & -50.91 & -39.00 \\
55 & -78.74 & -54.04 & -36.77 \\
60 & -84.75 & -53.35 & -40.27 \\
65 & -84.41 & -60.68 & -41.39 \\
70 & -87.91 & -58.14 & -40.25 \\
\hline
\end{tabular}

The experiment result shows GDP of country A has great impact when country A tax on fruit from country $\mathrm{B}$ and $\mathrm{C}$. The GDP of country $\mathrm{B}$ and $\mathrm{C}$ will be affected after taxed by country A, but the impact level is less than country A.

TABLE III.

THE INFLUENCE TO FRUIT YIELD OF COUNTRY A WHEN COUNTRY A TAXES ON FRUIT FROM FOREIGN COUNTRIES

\begin{tabular}{llll}
\hline Tax rate(\%) & $\begin{array}{l}\text { Fruit yield } \\
\text { of country A(\%) }\end{array}$ & $\begin{array}{l}\text { Fruit yield } \\
\text { of country B(\%) }\end{array}$ & $\begin{array}{l}\text { Fruit yield } \\
\text { of country C }(\%)\end{array}$ \\
\hline 5 & -5.31 & 1.11 & -2.95 \\
10 & -1.70 & -3.91 & -3.30 \\
15 & -10.20 & -4.81 & -8.36 \\
20 & -15.49 & -8.47 & -12.26 \\
25 & -16.28 & -5.48 & -10.77 \\
30 & -19.28 & -14.72 & -15.34 \\
35 & -31.34 & -16.60 & -18.18 \\
40 & -32.69 & -24.54 & -15.16 \\
45 & -47.79 & -30.28 & -16.37 \\
50 & -54.22 & -18.91 & -26.40 \\
55 & -56.80 & -40.73 & -22.23 \\
60 & -62.41 & -38.86 & -27.98 \\
65 & -64.97 & -41.11 & -30.61 \\
70 & -67.05 & -44.51 & -34.71 \\
\hline
\end{tabular}

The result of above table shows the consequence of collecting tax on foreign countries' fruits by country A. All fruit yield decrease and the largest decline of fruit yield is country A, which means the intention of accelerating the development of own country's fruit industry by tariff barriers could not be realized, and the result is contrary.

(2)the second experiment: initial condition and experiment result

TABLE IV.

CONDITION OF SIMULATION EXPERIMENT

\begin{tabular}{|c|c|c|c|}
\hline name & $\begin{array}{l}\text { amount(countr } \\
\text { y A) }\end{array}$ & $\begin{array}{l}\text { amount(country } \\
\text { B) }\end{array}$ & $\begin{array}{l}\text { amount(countr } \\
\text { y C) }\end{array}$ \\
\hline Agent & 100 & 100 & 100 \\
\hline Fruit tree & 10 & 30 & 50 \\
\hline tool & 20 & 40 & 60 \\
\hline gold mine & 100 & 100 & 100 \\
\hline cycle time & 850 & 850 & 850 \\
\hline
\end{tabular}
TABLE V.

THE COMPARISON OF YIELD BETWEEN FREE TRADE AND UNILATERAL TARIFF BARRIERS

\begin{tabular}{|c|c|c|c|c|c|c|}
\hline \multirow{2}{*}{$\begin{array}{l}\text { Operational } \\
\text { Cycle time }\end{array}$} & \multicolumn{6}{|c|}{$0 \%$ tax rate } \\
\hline & $\begin{array}{l}\text { A } \\
\text { yield } \\
\text { of } \\
\text { fruit }\end{array}$ & $\begin{array}{l}\text { A } \\
\text { yield } \\
\text { of } \\
\text { tool }\end{array}$ & $\begin{array}{l}\text { B } \\
\text { yield } \\
\text { of } \\
\text { fruit }\end{array}$ & $\begin{array}{l}\text { B } \\
\text { yield } \\
\text { of } \\
\text { tool }\end{array}$ & $\begin{array}{l}\text { C } \\
\text { yield } \\
\text { of } \\
\text { fruit }\end{array}$ & $\begin{array}{l}\text { C } \\
\text { yield } \\
\text { of } \\
\text { tool }\end{array}$ \\
\hline 51 & 12.14 & 2.17 & 11.70 & 2.53 & 12.54 & 3.30 \\
\hline 101 & 11.90 & 2.24 & 12.25 & 2.59 & 12.44 & 3.46 \\
\hline 151 & 11.58 & 2.14 & 11.46 & 2.48 & 12.92 & 3.48 \\
\hline 201 & 11.79 & 2.30 & 12.25 & 2.63 & 13.62 & 3.30 \\
\hline 251 & 11.23 & 2.11 & 12.06 & 2.61 & 12.63 & 3.26 \\
\hline 301 & 11.45 & 2.31 & 12.83 & 2.38 & 10.99 & 3.42 \\
\hline 351 & 12.09 & 2.12 & 12.25 & 2.68 & 12.66 & 3.52 \\
\hline 401 & 11.80 & 2.00 & 12.93 & 2.52 & 12.09 & 3.32 \\
\hline 451 & 11.58 & 2.23 & 13.17 & 2.63 & 12.63 & 3.31 \\
\hline 501 & 11.90 & 2.27 & 12.70 & 2.61 & 12.06 & 3.72 \\
\hline 551 & 12.18 & 2.38 & 12.82 & 2.63 & 10.87 & 3.40 \\
\hline 601 & 12.33 & 2.20 & 12.32 & 2.53 & 12.50 & 3.69 \\
\hline 651 & 11.40 & 2.28 & 12.55 & 2.42 & 12.24 & 3.42 \\
\hline
\end{tabular}




\begin{tabular}{|c|c|c|c|c|c|c|}
\hline 701 & 12.07 & 2.23 & 12.37 & 2.41 & 12.34 & 3.30 \\
\hline 751 & 12.79 & 2.11 & 11.98 & 2.50 & 12.34 & 3.62 \\
\hline 801 & 11.89 & 2.34 & 12.82 & 2.73 & 12.60 & 3.45 \\
\hline 851 & 12.59 & 2.17 & 11.87 & 2.54 & 12.03 & 3.59 \\
\hline average & 12.18 & 2.21 & 12.37 & 2.55 & 12.29 & 3.44 \\
\hline \multirow{3}{*}{$\begin{array}{l}\text { Time } \\
\text { Series }\end{array}$} & \multirow{2}{*}{\multicolumn{6}{|c|}{ Country A collects $40 \%$ tariff on imported fruit }} \\
\hline & & & & & & \\
\hline & $\begin{array}{l}\text { A } \\
\text { yield } \\
\text { of } \\
\text { fruit }\end{array}$ & $\begin{array}{l}\text { A } \\
\text { yield } \\
\text { of } \\
\text { tool }\end{array}$ & $\begin{array}{l}\text { B } \\
\text { yield } \\
\text { of } \\
\text { fruit }\end{array}$ & $\begin{array}{l}\text { B } \\
\text { yield } \\
\text { of } \\
\text { tool }\end{array}$ & $\begin{array}{l}\mathrm{C} \\
\text { yield } \\
\text { of } \\
\text { fruit }\end{array}$ & $\begin{array}{l}\mathrm{C} \text { yield } \\
\text { of } \\
\text { tool }\end{array}$ \\
\hline 51 & 1.48 & 2.36 & 6.58 & 3.53 & 6.05 & 3.77 \\
\hline 101 & 1.45 & 2.15 & 5.86 & 3.53 & 6.49 & 3.90 \\
\hline 151 & 1.39 & 2.59 & 6.85 & 3.02 & 5.94 & 3.92 \\
\hline 201 & 1.42 & 2.43 & 6.59 & 3.14 & 6.25 & 3.69 \\
\hline 251 & 1.47 & 2.50 & 6.60 & 3.15 & 6.39 & 4.25 \\
\hline 301 & 1.41 & 2.82 & 6.41 & 3.07 & 6.35 & 3.97 \\
\hline 351 & 1.59 & 2.33 & 6.45 & 3.25 & 5.84 & 3.79 \\
\hline 401 & 1.52 & 2.33 & 6.36 & 3.01 & 5.96 & 3.94 \\
\hline 451 & 1.38 & 2.45 & 5.97 & 3.12 & 6.26 & 4.02 \\
\hline 501 & 1.37 & 2.20 & 6.51 & 2.99 & 6.44 & 3.96 \\
\hline 551 & 1.29 & 2.38 & 6.00 & 3.24 & 6.30 & 3.54 \\
\hline 601 & 1.28 & 2.44 & 6.08 & 2.89 & 6.23 & 3.76 \\
\hline 651 & 1.60 & 2.54 & 5.83 & 3.42 & 6.17 & 3.99 \\
\hline 701 & 1.33 & 2.60 & 6.07 & 3.24 & 6.06 & 3.54 \\
\hline 751 & 1.40 & 2.45 & 6.72 & 3.31 & 5.48 & 3.91 \\
\hline 801 & 1.53 & 2.44 & 6.00 & 3.44 & 6.19 & 3.78 \\
\hline 851 & 1.42 & 2.78 & 6.21 & 3.37 & 5.98 & 3.74 \\
\hline average & 1.43 & 2.46 & 6.30 & 3.22 & 6.01 & 3.76 \\
\hline
\end{tabular}

The result of table $\mathrm{V}$ is still similar to the conclusion of first experiment, namely, tariff barriers could not achieve the purpose of protecting infant industry, on the contrary, it would damage its own infant industry and other countries' associated industries, and it would bring the most serious damage to its own infant industry.

There are three reasons to explain this phenomenon that are as follow:

Firstly, when country A taxes on imported fruit from country B or country $\mathrm{C}$, the price of imported fruit increases, so the price of imported fruit is higher than the fruit price of country A. As result, there are no buyers buying imported fruits in country A, and the producers of these imported fruit might turn to producing tool (because the production density of tools of country $\mathrm{B}$ and $\mathrm{C}$ are quite high, so, the number of tool producers increases, and the productivity of tool production declines less significantly.), which is part of the reason why the yield of tools of country B and C increase but the yield of fruit decrease. On the other side, some producers of tools in country A turn to producing fruits because they couldn't purchase fruits for the reason of fruit tariff, therefore, the demand of tools of country $\mathrm{B}$ and $\mathrm{C}$ might increase, and so it simulates the yield of tools increasing in these two countries.

Secondly, the price of imported fruits in country A increases, some agents who want to purchase low price fruits have to purchase domestic fruits, or they produce fruits by themselves. No matter how to select, the cost paid is higher than purchased imported fruits before. Those agents who purchased imported fruits before must be the producers of tools or gold, now, some of them produce fruits, some produce gold and some still produce tools but pay more money for fruits. The productivity of agents who turn to produce fruits is quite low (otherwise they wouldn't produce tools before). The productivity of agents who always produce fruits would decrease because new players take some fruit trees (the density of fruit tree is low, so the decline of productivity is more serious because new players join). On the other side, the number of agents who produce tool decrease, which lead to the density of selected mine increase, so the productivity of tool increases that is the reason why the yield of tool in country A increase (the establishing conditions for this reason is the density of tool is quite low, if the density of tool is very high originally, this effect disappears. More details would be showed in third experiment.).

Thirdly, there is one point need to explain, if the density of original natural resource (fruit trees, tool, and mine) is high, the decline of per capita density caused by new entrants is small, if the original density is very low, the decline of per capita density caused by new entrants is large. Namely, if original density is quite high, the decline of production caused by new entrants (because the density decreases) might be smaller than the increasing output caused by the increasing number of labors. We will make further verification to this point by third experiment.

In a word, because the fruit yield is limited by quotas exerted by tariff barriers, resource goes to other industries without tariff barriers (such as tool), and so the yield of tool increase.

(3)the third experiment: initial condition and experiment result

TABLE VI.

THE CONDITION OF SIMULATION EXPERIMENT

\begin{tabular}{lccc}
\hline name & $\begin{array}{l}\text { amount(countr } \\
\text { y A) }\end{array}$ & $\begin{array}{l}\text { amount(countr } \\
\text { y B) }\end{array}$ & $\begin{array}{l}\text { amount(countr } \\
\text { y C) }\end{array}$ \\
\hline Agent & 100 & 100 & 100 \\
Fruit tree & 1000 & 3000 & 5000 \\
tool & 2000 & 4000 & 6000 \\
gold mine & 100 & 100 & 100 \\
cycle time & 850 & 850 & 850 \\
\hline
\end{tabular}

TABLE VII.

THE YIELD OF FRUITS BEFORE COUNTRY A TAXES ON FRUIT

OF COUNTRY B AND C AND THE YIELD OF FRUITS AFTER COUNTRY A TAXES ON FRUIT OF COUNTRY B AND C

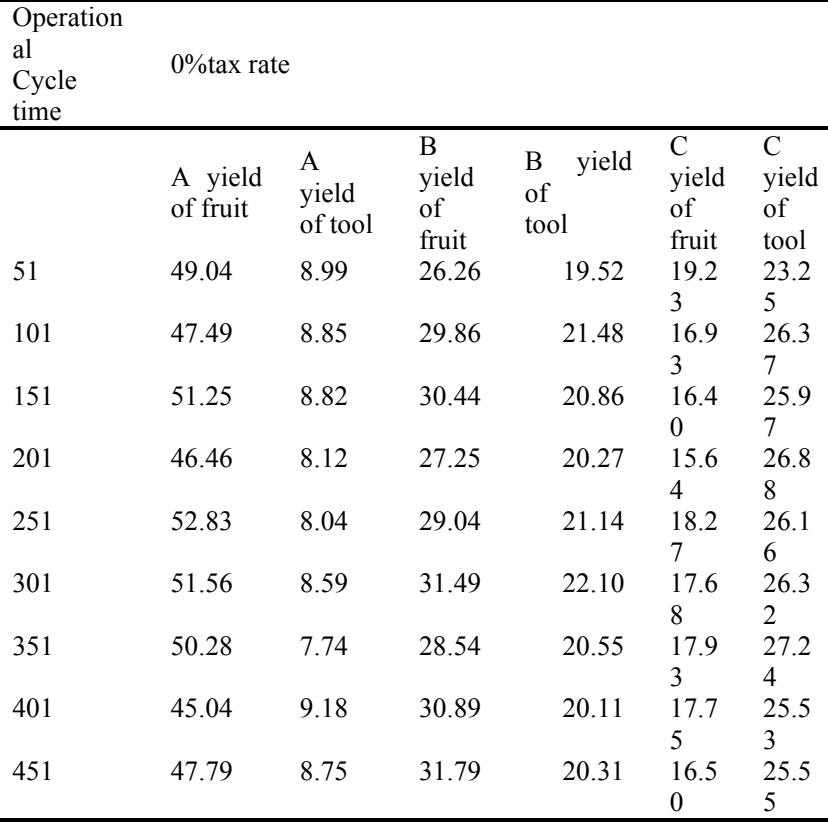


PAPER

COMPUTER SIMULATION RESEARCH FOR INFANT INDUSTRY THEORY BASED ON REPAST SIMPHONY

\begin{tabular}{|c|c|c|c|c|c|c|c|}
\hline 501 & 53.33 & 7.96 & \multicolumn{2}{|c|}{26.39} & 20.80 & $\begin{array}{l}18.4 \\
6\end{array}$ & $\begin{array}{l}27.7 \\
7\end{array}$ \\
\hline 551 & 50.41 & 7.94 & \multicolumn{2}{|c|}{25.98} & 22.31 & $\begin{array}{l}16.8 \\
7\end{array}$ & $\begin{array}{l}26.1 \\
0\end{array}$ \\
\hline 601 & 53.14 & 8.92 & \multicolumn{2}{|c|}{29.15} & 21.55 & $\begin{array}{l}18.4 \\
4\end{array}$ & $\begin{array}{l}26.2 \\
4\end{array}$ \\
\hline 651 & 47.22 & 9.33 & \multicolumn{2}{|c|}{30.45} & 20.84 & $\begin{array}{l}16.5 \\
9\end{array}$ & $\begin{array}{l}26.3 \\
2\end{array}$ \\
\hline 701 & 54.18 & 8.07 & \multicolumn{2}{|c|}{27.10} & 21.19 & $\begin{array}{l}17.5 \\
8\end{array}$ & $\begin{array}{l}27.2 \\
4\end{array}$ \\
\hline 751 & 50.55 & 8.99 & \multicolumn{2}{|c|}{28.26} & 21.57 & $\begin{array}{l}17.8 \\
4\end{array}$ & $\begin{array}{l}25.9 \\
0\end{array}$ \\
\hline 801 & 49.50 & 8.50 & \multicolumn{2}{|c|}{29.30} & 20.19 & $\begin{array}{l}15.9 \\
9\end{array}$ & $\begin{array}{l}26.1 \\
6\end{array}$ \\
\hline 851 & 50.46 & 8.51 & \multicolumn{2}{|c|}{30.19} & 21.04 & $\begin{array}{l}16.9 \\
8\end{array}$ & $\begin{array}{l}26.5 \\
8\end{array}$ \\
\hline Average & 50.78 & 8.55 & \multicolumn{2}{|c|}{28.96} & 20.93 & $\begin{array}{l}18.1 \\
0 \\
\end{array}$ & $\begin{array}{l}24.9 \\
2 \\
\end{array}$ \\
\hline \multirow[t]{2}{*}{$\begin{array}{l}\text { Operatio } \\
\text { nal } \\
\text { Cycle } \\
\text { time } \\
\end{array}$} & \multicolumn{7}{|c|}{ Country A collects $40 \%$ tariff on imported fruit } \\
\hline & $\begin{array}{l}\text { A } \\
\text { yield } \\
\text { of fruit }\end{array}$ & $\begin{array}{l}\text { A } \\
\text { yield } \\
\text { of tool }\end{array}$ & $\begin{array}{l}\text { B } \\
\text { yield } \\
\text { of } \\
\text { fruit }\end{array}$ & $\begin{array}{l}\text { B } \\
\text { yield } \\
\text { of } \\
\text { tool }\end{array}$ & $\begin{array}{l}\mathrm{C} \\
\text { yield } \\
\text { of } \\
\text { fruit }\end{array}$ & \multicolumn{2}{|c|}{$\begin{array}{l}\mathrm{C} \text { yield of } \\
\text { tool }\end{array}$} \\
\hline 51 & 2.51 & 7.72 & 6.02 & 20.22 & 4.41 & \multicolumn{2}{|c|}{26.74} \\
\hline 101 & 2.22 & 8.58 & 5.19 & 21.15 & 4.22 & \multicolumn{2}{|c|}{25.76} \\
\hline 151 & 2.53 & 8.60 & 5.04 & 21.75 & 4.16 & \multicolumn{2}{|c|}{25.08} \\
\hline 201 & 3.01 & 8.43 & 3.42 & 21.86 & 2.93 & \multirow{2}{*}{\multicolumn{2}{|c|}{$\begin{array}{l}27.63 \\
26.95\end{array}$}} \\
\hline 251 & 2.76 & 7.82 & 4.81 & 20.56 & 3.44 & & \\
\hline 301 & 2.44 & 8.82 & 4.77 & 20.57 & 3.54 & \multicolumn{2}{|c|}{$\begin{array}{l}26.95 \\
25.92\end{array}$} \\
\hline 351 & 2.12 & 8.25 & 4.85 & 21.39 & 3.61 & \multicolumn{2}{|c|}{26.89} \\
\hline 401 & 2.50 & 8.76 & 3.85 & 20.37 & 3.48 & \multicolumn{2}{|c|}{27.42} \\
\hline 451 & 2.11 & 8.56 & 5.52 & 22.00 & 2.93 & \multicolumn{2}{|c|}{26.32} \\
\hline 501 & 2.49 & 8.68 & 5.01 & 22.66 & 3.20 & \multicolumn{2}{|c|}{28.11} \\
\hline 551 & 2.79 & 8.38 & 6.07 & 21.00 & 2.58 & \multicolumn{2}{|c|}{28.08} \\
\hline 601 & 2.38 & 8.30 & 4.43 & 21.70 & 3.97 & \multicolumn{2}{|c|}{27.71} \\
\hline 651 & 2.63 & 9.26 & 4.11 & 19.66 & 3.44 & \multicolumn{2}{|c|}{27.06} \\
\hline 701 & 2.44 & 7.34 & 5.16 & 21.31 & 2.97 & \multicolumn{2}{|c|}{28.62} \\
\hline 751 & 2.24 & 8.67 & 4.04 & 22.44 & 3.42 & \multicolumn{2}{|c|}{27.49} \\
\hline 801 & 2.25 & 8.27 & 5.26 & 21.25 & 3.11 & \multicolumn{2}{|c|}{27.63} \\
\hline 851 & 2.67 & 8.36 & 5.15 & 21.96 & 4.76 & \multicolumn{2}{|c|}{27.97} \\
\hline & 0.00 & 0.00 & 0.00 & 0.00 & 0.00 & \multicolumn{2}{|c|}{0.00} \\
\hline Average & 2.48 & 8.40 & 4.86 & 21.28 & 4.58 & \multicolumn{2}{|c|}{27.36} \\
\hline
\end{tabular}

In third experiment, we increase the tool density of country A to 1000, the result shows the tool yield of country A didn't increase because country A taxes on fruits from country A and B, which is not the same as second experiment. The reasons are:

At first, part of agents who originally manufacture tool switch to producing fruits or gold because the price of imported fruits increased and they couldn't survive without fruit, so the number of agents manufacturing tools decreased, which result in the decline of tool yield.

Additionally, the number of tool producers decline, leading to the increase of per capital tool density, which is beneficial to improve the productivity of tool and the tool yield increased as a result. But the original tool density is quite high, so the increase of tool yield is little. The impact of the above two directions are opposite, one is negative and the other is positive. The original tool density is higher, the impact to tool yield is less. Therefore, when the original tool density reaches very high level, the total impact is negative, which is the tool yield decrease.

\section{CONCLUSION}

Our paper's conclusion is the traditional theory--- "it is useful that power country provides tariff barriers to protect infant industry's development."-----works on extremely rare scenarios, under the condition that the profit margin of all industrial products are more or less equal and the developed country could satisfy the market demand of these products. However, this scenario rarely happens. Thus, in the most of situations, protecting infant industry by tariff barriers wouldn't get the expected effect. On the contrary, trade protection would be harmful to all countries, and country which implements the tariff barriers would get more negative impacts on its own industries. Our paper verifies this impact by computer simulation.

In our computer simulation research, the behavior capability of agent is very simple - agents select their behaviors from the selection sets of production and trade. Agents have no learning and innovation ability, and they already know market prices. These hypotheses are still too ideal to reflect the reality. In the future, we will modify these hypotheses step by step in order to make the simulation more close to the reality.

\section{REFERENCES}

[1]D.H.Wang, L.T.Gong. "Development of Infant Industry," The Journal of Quantitative and Technical Economics, vol.23,No.3, pp. 24-36, March 2006.

[2] J. Holland. Hidden Order. Shang Hai: Shanghai Education Publishing House of science and technology , 2000 .

[3] S.Liu, Y.Zhao. "A summary of economic simulation research on modeling based agent," Modern economic information, No.19, pp. 197-199, October 2012.

[4] X.C.Zheng. "Enlightenment from Complexity Theory in Constructing Ecological Civilization," Science and Technology Management Research, vol.33,No.9, pp. 254-258, September 2013.

[5] Y.C.Zhang, Y.S.Kang. "Constructing the simulation model of personalized recommendation system of e-commerce swarm platform and based on the theory of social network," Computer CD Software and Applications, No.21, pp. 124-125, November 2012.

[6] Y.F.Cheng,Y.S.Dong,L.Q.Deng. "Comparison of Agent-based Simulation Platforms," Journal of System Simulation, Vol. 23 Suppl. 1, pp. 110-116, July 2011.

[7] X.Y.Shao.Quantitative Model and Simulation on Impacts of Technical Barriers to International Trade. Shenyang: Northeastern University, 2009

[8] J.Y.Jiang. Evaluation Methods of Technical Barriers to Trade and Analysis of Influece to Economy via Simulation. Shenyang: Northeastern University, 2009

\section{AUTHORS}

Y.F. Lin is with Guangxi University of Finance and Economics, Nanning, China (e-mail: 12832386@ qq.com).

Z.E. Nong, was also with Guangxi University of Finance and Economics, Nanning, China. (e-mail: zenong@163.com).

Submitted 25 May 2015. Published as resubmitted by the author 25 june 2015 . 